\title{
Practice teaching system to cultivate talents of Information Management
}

\author{
Shuren Zhu \\ School of Information \\ Guangdong University of Finance \& Economics \\ Guangzhou, China \\ Zhusr@gdufe.edu.cn
}

\author{
Yanhua He \\ School of Information \\ Guangdong University of Finance \& Economics \\ Guangzhou, China \\ yz445702692@163.com
}

\begin{abstract}
Based on occupation development framework of engineering technology talents, analyzed the existing main problems in finance and economics that the specialty talent education of information management and information system is lack of engineering ability and occupation quality, proposed use an engineering training method to reform professional experimental courses of culturing students' practice ability, and elaborated engineering practice teaching system and its practice of application type talents training of information system.
\end{abstract}

Keywords-occupation development framework; application type talents training; engineering practice

\section{INTRODUCTION}

The internationally recognized occupation development framework of engineering technology professionals includes capability and innovation of learning and applying knowledge, engineering practice ability, technical and business leadership, interpersonal communication skills, professional ethics, social responsibility and sustainable development etc [1]. The basic courses of information systems professional is the most important curriculum system to develop engineering and technical talents, and database system engineer is one of the greatest demands in engineering and technical personnel of the information society. The national information process is involved in all walks of life, and the construction and operation of information systems in enterprises and national are the mainstream demands of information management and information system professionals in the current and future [2].

Although the number of information talents cultured in domestic college has being increased rapidly, the lack of application talents of high-end information systems seriously hindered the development of information service [3]. The important reasons for this phenomenon as follows: domestic IT-related professional teaching was still stuck in the traditional training model, basic theoretical knowledge and experiments against individual's practical ability constituted the main body of teaching, a general lack of the ability of students' engineering and occupation training and lack of required teaching environment for these training [4]. Developing and operating enterprise information systems with an engineered and standardized method became common understanding in industry [5][6]. People who engaged in the development and service of information systems should not only have a solid theoretical foundation, rigorous scientific literacy, professional knowledge and good creativity, but also should have strong project design and implementation capacities and good occupation quality. Therefore, it is urgent to comprehensively reconstruct the undergraduate information system specialty training teaching system and gradually establish a teaching system of engineering practice in order to cultivate students' engineering development and operation ability and the occupation quality and form a scientific training system melt basic theory, experimental teaching, and engineering practice as one. So that students' professional knowledge, innovation ability, construction capability and the occupation quality could be fully developed [7][8].

In the field of top-notch talents practice teaching of information management and information system, we have explored it for more than four years. A significant result has been achieved through engineering reform the training courses related to practice ability. The paper makes summarize of this kind of teaching system.

\section{PRACTICE TEACHING SYSTEM}

Training applied talents relates to legitimately set and optimize theoretical curriculum, experimental course, internships and engineering practices etc, it is a complex comprehensive teaching reform practice. Under the guidance of engineering teaching ideas, the application type talents practice teaching system of information systems used multimedia technology combined with specific teaching cases and basic environment of engineering practice education to explore an engineering teaching mode of culturing application-oriented personnel of information system. It also aimed to develop students' habits of selflearning and collaborative learning and achieve the target of enhancing their learning initiative, fostering innovation and improving teaching effectiveness through the proposition, analysis, implementation and evaluation of engineering tasks in the teaching process. The engineering practice teaching system of information management and information systems implemented in digital business and business innovation in our school could be simply generalized with engineering teaching philosophy, engineering practice courses and engineering practical training.

Figure 1 is application type talents practice teaching system model. It strengthens the foundation and practice by optimizing curriculum and structure. On one hand, it focuses on training the awareness of engineering and application capabilities .On the other hand, it not only strengthens the training of professional planning and ethics programs, but also builds a generous education foundation and meets the 
needs of personnel training system and personnel training platform of different levels.

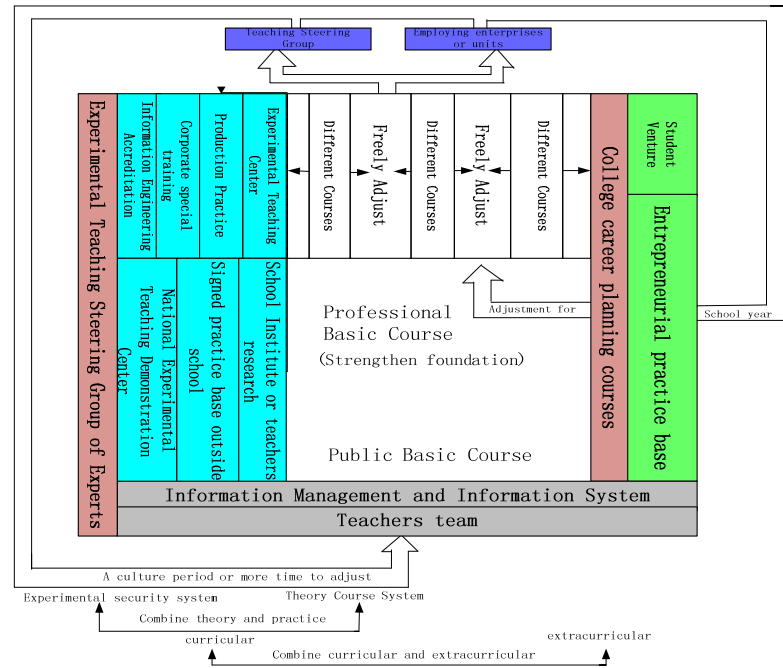

Figure 1 Application type talents practice teaching model of Information System

\section{A. Engineering teaching philosophy}

Engineering teaching philosophy combines the establishment of engineering ability and basic theory teaching with the development of professional capacity. It considers engineering teaching as one of the core task of culturing talents. Through comprehensive reform professional training model, adjust curriculum, enrich teaching content and improve teaching methods of Information Management and Information Systems, and fully reflect the idea of engineering capability cultivation and professional quality training in the process of teaching, it formed a training program which melts basic theory, experimental teaching and engineering practice as one. Therefore, students could comprehensive and balanced develop their abilities and meet the needs of modern information service industry.

\section{B. Engineering practice courses}

Based on required personal development ability, team development capability, system research and development capabilities, system operational ability and the capability of equipment applications, sets five unique engineering practice courses.

1) Program design course: To train student's personal project development capabilities.

2) Database systems design course: To train student's capability of database systems engineer.

3) Information systems analysis and design: To train student's ability of doing medium and large systems projects.

4) Management information system course: To develop student's operational capability of medium and large systems projects.

5) Curriculum design of computer systems and networks: To culture student's capacity of equipment selection and application.

\section{Engineering practical training}

Engineering practical training sets both engineering teaching stage and internship stage, and regards engineering quality training as the most important period for students' cultivation. During engineering teaching stage, it independently sets up several credit courses which aim to develop student's engineering capability and professional quality. It also reforms and enriches teaching contents of traditional core courses include Program design, database systems, management information systems and computer networks and introduces curriculum design. During graduation internship period, it establishes a full-time internship system lasting six months, sets up practice base in the enterprise and further develops student's engineering skills and professional qualities through real business atmosphere and development environment.

\section{Construction engineering practice teaching conditions}

According to the demand of engineering practice teaching, comprehensively adjust teaching contents and enhance aspects of engineering practice. Besides, change the traditional teaching mode and with a characteristic of teacher-guided organizations, student's hands-on cooperation and teacher-student interaction in engineering practical courses that involve program design, database systems, management information systems, information systems analysis and design and computer network to develop student's abilities of thinking and analyzing problems independently, operational capability, innovation ability, communication skills, capability of preparing documents, teamwork, project management capabilities and the ability of engineering.

Putting engineering capability and professionalism practical into course evaluation system, it formed an assessment model counterpoises theoretical knowledge and practical ability. It considers system implementation, documentation and evaluation programs as assessment indicators and introduces team scoring system in some courses. By collecting feedbacks from companies and students and putting them into teaching evaluation system, it created a good development and constraint mechanism and a solid foundation to further improve the quality of teaching.

The construction of experimental teaching is guided by engineering training concept. It insists in considering system software, ROSE UML, power design as the core development case tools and regards networks, servers, desktop systems as platform to set up a comprehensive lab environment synchronized with industries. These provide a strong infrastructure to support the teaching of engineering practice. 


\section{TEACHING CONTENTS OF ENGINEERING PRACTICE CREDIT COURSES}

\section{A. Program design course}

The purpose of Program Design Course is to develop student's personal project capability and improve their qualities in software process management, algorithms understanding and design, programming style and skills, basic knowledge application. The main form of this curriculum is guide students to independently develop projects. Teachers give a number of projects in moderate size for students to choose, and then require them to conduct a detailed project planning, manage development time and comprehensive measure the size, reliability, quality of project.

\section{B. Information systems analyze and design}

Information systems analyze and design is aim to develop student's ability of teamwork. It allows students to use the latest software development tools (such as ROSE UML, etc.) to get real development experience in a team environment which would help students improve their abilities of project planning, team organization, work assignments and communication.

The main form of this curriculum is to establish an exploitation team and emphasize collaboration and division of labor and then complete pre-set items. It requires each team consists of three students. The project development is divided into four phases. The first phase is requirements analysis and design which is used for each team to prepare relevant documents and public defense. The second phase is realization used for each group to write code and unit test. The third phase is task change used to choose the best program which was completed as the base for next phase of encoding code and simulate the condition of code review in real project situations. The last phase is protect and test used for teachers to give next project requirements so that students could add new features in the base of code they chosen and simulate the changes of demand for reality project.

\section{Database systems design course}

This curriculum uses a manner of combining teachers propose topics, students select topics and teachers review to complete the topics design. Each development team consists of three students, they select an appropriate database management system and development tools that suitable for the team to develop a network database application system based on B / S mode. Each team member has different task such as Project administrator, DBA, systems analysts, system designers, programmers, testers. They must fully understand the whole process of the entire design and can systematic grasp each aspects of the whole process from demonstration program, process design, programming, testing to final design document writing. The achievement of design contains a detailed design report of various stages of the design, a system running applications and a reply performance of curriculum design for 30 minutes, a demonstration of system running and a report about the situation of division and cooperation.

\section{Management information system course}

The purpose of management information system course is to develop student's operational capability of medium and large systems projects and improve their attainments in feasibility study, bidding, demand investigation and analysis, plan development, project implementation as well as reports and statements, exchange and communication, etc. This curriculum requires students to organize a team with three members and complete a medium-scale project of management information system. The exploitation of project divided into five stages include project proposals writing and bidding, Project Plan and demands survey, model analyze and system design, project implementation, project acceptance and delivery.

\section{E. Curriculum design of computer systems and networks}

The purpose of curriculum design of computer systems and networks is to cultivate the capacity of equipment selection and application. It allows students to configure in a device environment that full compliance with the practical application conditions and ensures the contents that students learned could fit current mainstream technology development. This curriculum faces to practical application and its main form is to guide student deploy and debug servers, switches, routers and desktop computers and other important system software. The main contents of this course include configure routers and switches, design and implement a multi-protocol complex network which contains LAN and WAN, configure desktop System, network services and application server.

\section{ENGINEERING PRACTICE SETTINGS}

Graduation practice and graduation design are the last links in the undergraduate teaching practice, they are also the most comprehensive and initiative parts of practice. In this period, students could apply the comprehensive knowledge and skills to solve practical problems of scientific and production. In order to achieve a seamless link with enterprises and strengthen student's ability of engineering practice, we adopted a method that combines students use their own links to find graduation practice place with school selection. To this end, we set up training bases in Guangzhou IAC Software Co., Ltd. as well as a dozen information systems services companies. We also hired engineers in the enterprise as graduate design and internship instructor and sent students to practice base in the end of the 7th semester. For those students who could contact graduation design units themselves or has already signed an employment agreement, we helped them determine school instructor and relate formalities and conducted them a six-month full-time internship which is required. Students participated in business operations and project development could have the chance to experience the real business and project 
development environment and direct feel the pulse of the industries and improve their engineering capabilities and professionalism. There are both thesis tutor and business tutor who are maintaining regular and close contact. They could develop a reasonable training plan for individual students. During graduation period, students must feedback their own work and learning conditions in the enterprise to the school and thesis tutor regularly ensure the training plan smoothly.

After students graduated from school per year, it is necessary for students to connect with engineering internships. It also requires corporate mentors and internships assess the students we cultured. The purpose of assessment is to collect enterprise opinions of business professional training and clearly understand the strengths and weaknesses of professional training system so that students could better adapt to the needs of the industry.

\section{ACHIEVEMENT OF IMPLEMENTATION}

The engineering practice teaching system of culturing application type talents of information systems has been fully implemented for students of information management and information system. The total number of students it involved was more than 300. After nearly four years of practice, the overall quality of students has been significantly enhanced and employment level has been improved obviously. It is accumulated that the number of students who pass the national engineer certification exam has reached 62\%.That included database systems engineers, information systems management engineers, system integration and project management engineers, information systems supervising engineers, information security engineers etc.

\section{ACKNOWLEDGEMENT}

This work is supported by funds from the Natural Science Foundation of Guangdong Province under Grant No. 10151032001000001, and "Research and practice of developing top-notch talents in digital business and business innovation" of 2012 Guangdong Province higher education reform project

\section{REFERENCES}

[1] Luo bing, Zhao zhihong and Shao dong. Construction and implementation of software engineering practical teaching system. Computer education, 2010(4):25-28.

[2] Mao guojun, Fang juan and Yi xiaolin. Exploration and practice of the cultivation of engineering application talents. Chinese University Teaching 2012(9):43-45.

[3] Han likai, Lei weijun and Mao yan. The computer personnel training and teaching practice in application type undergraduate colleges. Computer education, 2012(2):78-80.

[4] Zhuang jingming. Discussion on a new model of experimental teaching of computer programming course. Computer education,2013(4):18-20.

[5] Wang shan, Sa shixuan. Introduction to database systems (Fourth Edition). Beijing, Higher Education Press, 2011.

[6] Zhang yujing, Cui xinhui. Discussion on the teaching reformation of database principle. The financial teaching and research financial, 2010(3) : 53-54.

[7] Zhou lijuan. Reformation and optimization of database teaching system. Higher Education Forum. 2009(1):59-61.

[8] Wang zesheng, Chen zihui. Exploration of laboratories management mechanism in Colleges and Universities. Laboratory Science, 2012(6) : 119-121. 